\title{
Enhanced sensitivity of celecoxib in human glioblastoma cells: Induction of DNA damage leading to p53-dependent $G_{\text {, cell cycle }}$ arrest and autophagy
}

\author{
Khong Bee Kang*, Congju Zhu, Sook Kwin Yong, Qiuhan Gao and \\ Meng Cheong Wong
}

Address: Brain Tumour Research Laboratory, Division of Medical Sciences, Humphrey Oei Institute of Cancer Research, National Cancer Centre, 11 Hospital Drive, 169610, Singapore

Email: Khong Bee Kang* - dmskkb@nccs.com.sg; Congju Zhu - dmszcj@nccs.com.sg; Sook Kwin Yong - nmsyskg@nccs.com.sg; Qiuhan Gao - chrisgqh@yahoo.com.sg; Meng Cheong Wong -dmswmc@nccs.com.sg

* Corresponding author

Published: 25 August 2009

Molecular Cancer 2009, 8:66 doi:10.1186/1476-4598-8-66
Received: 8 April 2009

Accepted: 25 August 2009

This article is available from: http://www.molecular-cancer.com/content/8/1/66

(c) 2009 Kang et al; licensee BioMed Central Ltd.

This is an Open Access article distributed under the terms of the Creative Commons Attribution License (http://creativecommons.org/licenses/by/2.0), which permits unrestricted use, distribution, and reproduction in any medium, provided the original work is properly cited.

\begin{abstract}
Background: Selective cyclooxygenase (COX)-2 inhibitors elicit anti-proliferative responses in various tumours, however the underlying anti-tumour mechanisms are unclear. Mutational inactivation of the tumour suppressor $\mathrm{p} 53$ gene is frequent in malignant gliomas. The role of $\mathrm{p} 53$ mutation in the anti-tumour responses of the selective COX-2 inhibitor celecoxib in human glioblastoma cells is unknown. In this study, we used human glioblastoma cells with various p53 status; U87MG (with high and low p53 functional levels), LN229 (functional p53) and U373MG (mutant p53) cells. Inhibition of p53 was achieved in U87MG cells transfected with E6 oncoprotein (U87MG-E6) and treated with pifithrin- $\alpha$, a reversible inhibitor of p53 (U87MG-PFT). We investigated whether the anti-glioblastoma responses of celecoxib were p53dependent, and whether celecoxib induced DNA damage leading to $p 53$-dependent $G_{1}$ cell cycle arrest, followed by autophagy or apoptosis.

Results: Our findings demonstrated that celecoxib concentration-dependently reduced glioblastoma cell viability, following 24 and 72 hours of treatment. Inhibition of functional p53 in glioblastoma cells significantly reduced the anti-proliferative effect of celecoxib. In U87MG cells, celecoxib ( 8 and $30 \mu \mathrm{M})$ significantly induced DNA damage and inhibited DNA synthesis, corresponding with p53 activation. Celecoxib induced $G_{1}$-phase cell cycle arrest, accompanied with p2I activation in U87MG cells. Cell cycle progression of U87MG-E6 and U87MG-PFT cells was not affected by celecoxib. In parallel, celecoxib induced $G_{1}$ cell cycle arrest in LN229 cells, but not in U373MG cells. Autophagy was induced by celecoxib in U87MG and LN229 cells, as shown by the significantly greater population of acridine orange-stained cells and increased levels of LC3-II protein (in comparison with non-treated controls). Celecoxib did not induce significant autophagy in U87MG-PFT, U87MG-E6 and U373MG cells, which lack functional p53. Regardless of p53 status, celecoxib caused no significant difference in apoptosis level of U87MG, U87MG-PFT, U87MG-E6 and U373MG cells.
\end{abstract}

Conclusion: Our findings reveal that $\mathrm{p} 53$ increases human glioblastoma sensitivity to celecoxib. Celecoxib inhibits glioblastoma cell viability by induction of DNA damage, leading to $p 53$-dependent $G_{1}$ cell cycle arrest and p53-dependent autophagy, but not apoptosis. 


\section{Introduction}

Despite conventional therapy of surgical resection, radiotherapy and chemotherapy, the median survival of malignant glioma patients remain poor. Most patients with glioblastoma multiforme survive less than 2 years after diagnosis [1]. Therapeutic improvements are needed to extend the survival of malignant glioma patients. Cyclooxygenase (COX)-2, an isoform of COX which is the rate-limiting enzyme in conversion of arachidonic acid into prostaglandins, is inducible in the presence of cytokines and growth factors during inflammation [2]. The importance of COX-2 in carcinogenesis and brain tumour progression is highlighted by the detection of COX-2 in brain tumours $[3,4]$ and COX-2 overexpression in gliomas associated with poor prognosis [5]. Targeting COX-2 with selective COX-2 inhibitors (NS-398, SC-236 and celecoxib) has proven effective to reduce human glioblastoma cell viability in vitro [4,6-9] and in rodent models [6,9-11]. Celecoxib is the only selective COX-2 inhibitor approved by the FDA for adjuvant treatment of patients with familial adenomatous polyposis.

The molecular events underlying the anti-tumour properties of COX-2 inhibitors are not fully understood. Several mechanisms have been proposed in various tumour models. COX-2 inhibition by celecoxib induces $G_{1}$ cell cycle arrest, corresponding with activation of $\mathrm{G}_{1}$-phase cyclinCDK inhibitors, p21 and p27 [12-14]. Celecoxib activates apoptotic proteins BAD, caspases and PARP, followed by cell apoptosis and reduced tumour cell proliferation [9,13-17]. Anti-tumour mechanisms of COX-2 inhibitors also include inhibition of tumour angiogenesis [18], inhibition of prostaglandin-induced immunosuppressive activity [19] and increased DNA damage/reduced DNA repair capacity [20]. Peroxidation of arachidonic acid into prostaglandins by COX generates reactive oxygen species and free radicals, which induce DNA damage and tumourigenicity [21]. Inhibition of COX by COX inhibitors aspirin [22], nimesulide [23], rofecoxib and celecoxib [24] protects DNA from oxidative damage by scavenging hydroxyl radicals and superoxide in vitro in non-tumour models. However, prevention of DNA damage by COX inhibitors has not been reported in tumour cells. In contrast, aspirin significantly induces DNA damage of HT-29 human colon carcinoma [25], whereas celecoxib causes DNA damage in MCa-35 murine mammary and A549 human lung cancer cells [26]. Whether COX-2 inhibitors induce DNA damage in glioblastoma cells is unclear.

Mutational inactivation of the tumour suppressor gene p53 (a regulator of cell growth and death) is frequently found in human tumours, with p53 mutation/inactivation reported in $63-65 \%$ of high-grade gliomas [27]. Induction of DNA damage initiates a cascade of signalling with p53 activation (phosphorylation at Ser 15 and Ser 20) and subsequent transcriptional activation of p53 response genes (including p21, GADD45, BAX, PUMA, $\mathrm{Bcl} 2$ and NOXA), thus provoking cell cycle arrest and/or apoptosis [28]. Genotoxic stress caused by DNA-damaging agents also induce p53-dependent autophagy $[29,30]$, the type II programmed cell death characterised by the formation of cytosolic double-membrane vesicles (autophagosomes) that engulf cellular content by digestion, when fused with lysosomes [31]. The mechanisms of p53-dependent induction of autophagy are not fully understood, but are thought to involve both the transcription-independent functions (e.g. activation of the nutrient energy sensor AMP kinase) and transcription-dependent functions (e.g. upregulation of mTOR inhibitors PTEN and TSC1, or p53-regulated autophagy and cell death gene DRAM) [30,32]. Anti-tumour mechanisms by COX inhibition have been shown to be either p53-dependent $[33,34]$ or p53-independent in various cancer and noncancer cells. The anti-proliferative mechanism of COX-2 inhibitors underpin by autophagy induction in tumours is unclear. To date, only one recent report suggests that celecoxib induces both autophagy and apoptosis, mediated by P-glycoprotein independent of p53 mechanisms, in hepatocellular carcinoma cells [35]. The role of p53 in celecoxib-induced autophagy and celecoxib-induced antiproliferative responses clearly needs to be verified.

In this study, we investigated (a) whether the anti-proliferative response induced by celecoxib was dependent on the presence of functional p53 and b) whether celecoxibinduced DNA damage resulted in p53-dependent $G_{1}$ cell cycle arrest, followed by apoptosis or autophagy. We studied the effect of celecoxib in human glioblastoma cells with various p53 status; U87MG cells with high and low levels of p53 [by both genetic (oncoprotein E6) and pharmaceutical intervention (pifithrin- $\alpha$ )], LN229 (with wild type p53 function despite a p53 mutation in the coding sequence [36]) and U373MG (with mutant p53) cells. Our findings show that the anti-proliferative sensitivity of celecoxib is dependent on p53 in human glioblastoma cells. We further demonstrate that celecoxib enhances glioma cytotoxicity by induction of DNA damage and p53dependent $\mathrm{G}_{1}$ cell cycle arrest, followed by p53-dependent autophagy but not apoptosis.

\section{Results \\ Celecoxib concentration-dependently inhibited human glioblastoma cell viability, with enhanced anti- proliferative response by the presence of functional p53}

Celecoxib concentration-dependently reduced the viability of human glioblastoma cells U87MG, which contains wild-type p53 (Figure 1A-D). To determine whether the anti-proliferative response to celecoxib was dependent on p53, we first compared the effect of celecoxib on viability of U87MG-E6 and U87MG cells. Viral oncoprotein E6 inhibits $\mathrm{p} 53$ function by abrogating specific DNA binding and transactivation of p53, sequestering p53 into the cyto- 
A. $24 \mathrm{~h}$

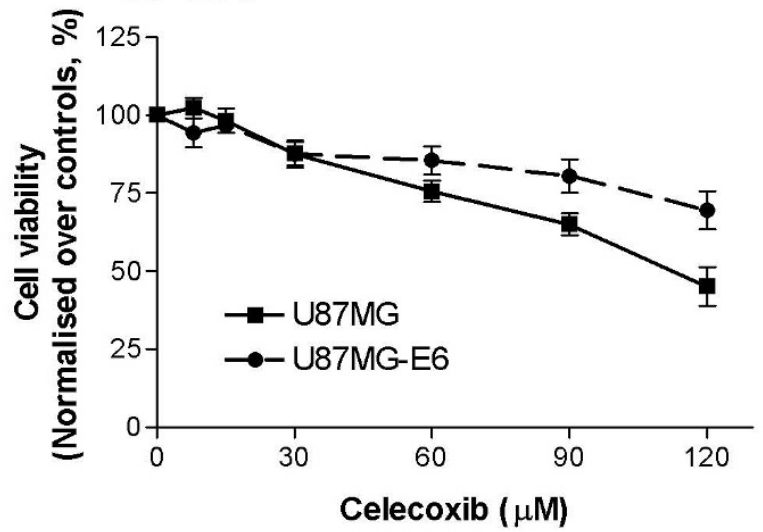

C. $24 \mathrm{~h}$

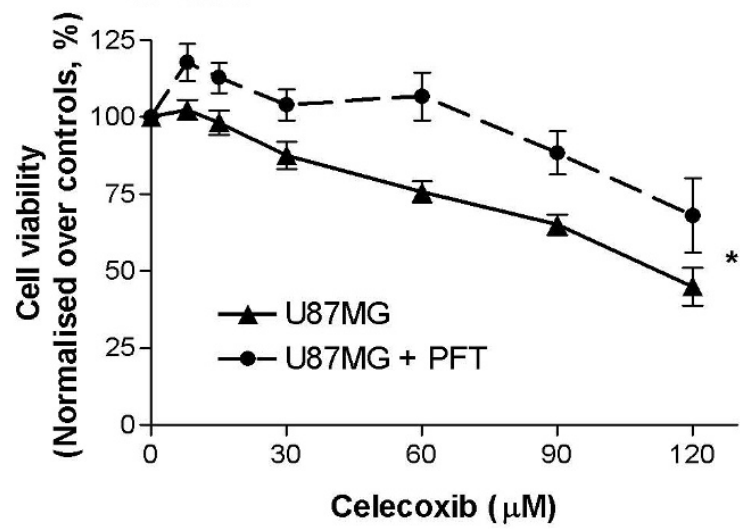

E. $24 \mathrm{~h}$

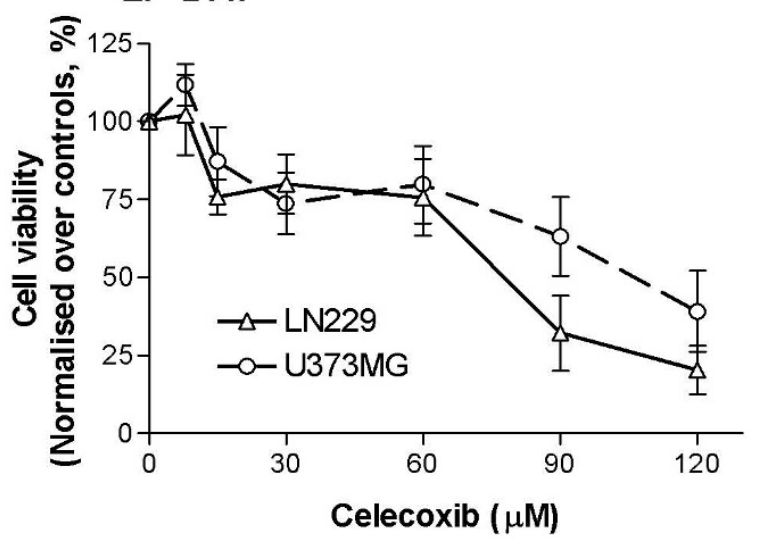

B. $72 \mathrm{~h}$

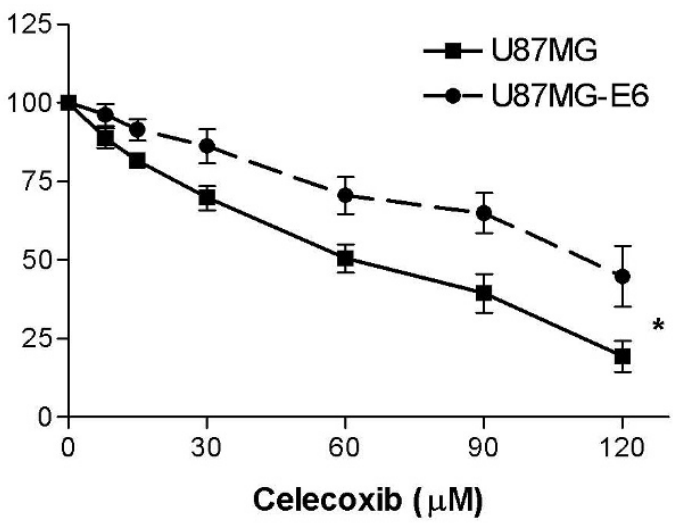

D. $72 \mathrm{~h}$

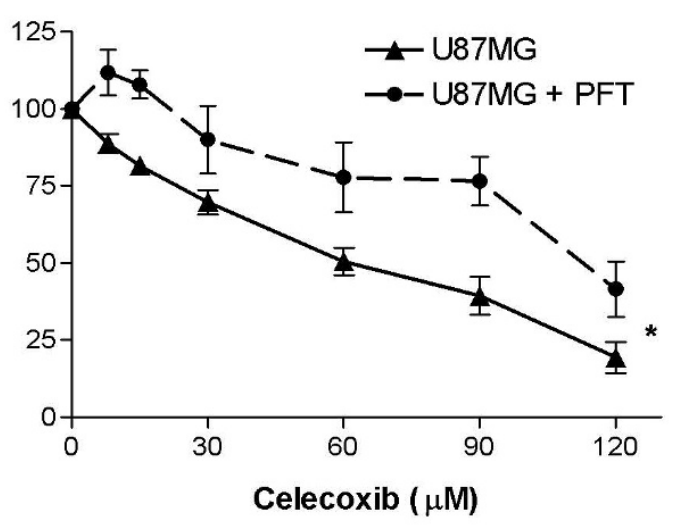

F. $72 \mathrm{~h}$

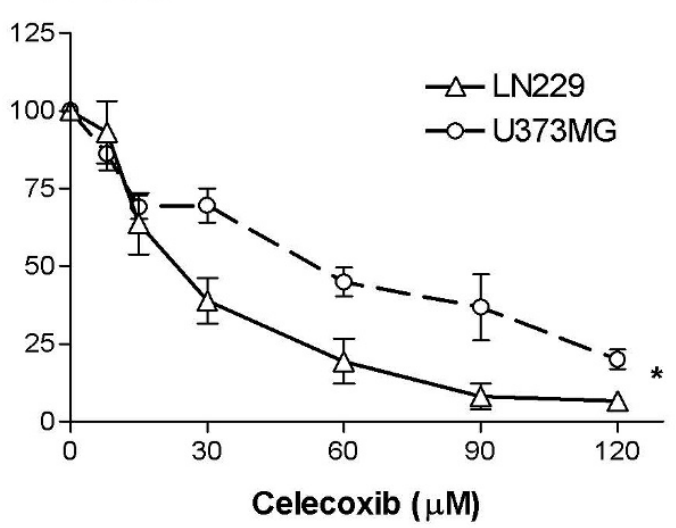

Figure I

Concentration-dependent response of celecoxib on viability of human glioblastoma cells. Cells were treated with a series of celecoxib concentrations for 24 (A, C, E) and 72 (B, D, F) hours. In some cases, U87MG cells were pre-treated with PFT $(25 \mu \mathrm{M})$ for 30 minutes prior to celecoxib treatment. Cell viability was measured by MTT assays and presented as absorbance readings at $570 \mathrm{~nm}$ normalised against controls. Values are expressed as mean \pm S.E.M $(n=3-10)$. $* P<0.05$ significantly different between two concentration-dependent response curves (2-way ANOVA). 
plasm and accelerating its degradation [37]. Inhibition of p53 by oncoprotein E6 reduced the sensitivity of U87MG cells to celecoxib, as shown by the enhanced U87MG-E6 cell viability following celecoxib treatment, compared with non-transfected U87MG cells (Figure 1A-B). Following 72 hours of celecoxib treatment, U87MG-E6 cells were significantly more viable than U87MG cells $(P<0.05$, Figure $1 \mathrm{~B})$. The prerequisite of p53 to protect U87MG cells from the anti-proliferative effect of celecoxib was confirmed with U87MG cells treated with PFT (U87MG-PFT). PFT- $\alpha$ inhibits p53 by reversibly blocking p53-transcriptional activation [38]. Inhibition of p53 by PFT significantly reduced sensitivity of U87MG cells to celecoxib, with enhanced U87MG-PFT cell viability at 24 and 72 hours following celecoxib treatment, compared with untreated U87MG cells $(P<0.05$, Figure 1C-D).

The p53-dependent anti-proliferative response induced by celecoxib was also shown in LN229 and U373MG glioblastoma cells. Celecoxib ( 24 and 72 hours treatment) inhibited viability of LN229 and U373MG cells in a concentration-dependent manner (Figure 1E-F). At 72 hours of celecoxib treatment, U373MG cells (with mutant p53) were significantly more viable than LN229 cells (with functional p53; $P<0.05$, Figure $1 \mathrm{~F}$ ). These results parallel the enhanced anti-proliferative responses of celecoxib in U87MG cells (high level of functional p53), compared with U87MG-E6 and U87MG-PFT (low functional level of p53), thus verifying a p53-dependent anti-proliferative response induced by celecoxib. In subsequent experiments, we tested the effect of celecoxib at $8 \mu \mathrm{M}$, a concentration equivalent to human plasma concentration following consumption of $800 \mathrm{mg} / \mathrm{kg}$ celecoxib daily (the FDA approved dosage for familial adenomatous polyposis [39]), as well as at $30 \mu \mathrm{M}$, a lower than $\mathrm{EC}_{50}$ concentration.

\section{Celecoxib activated p53}

We verified that stable transfection of U87MG cells with oncoprotein E6 inhibited p53 protein expression (Figure 2A). In U87MG and LN229 cells (both with functional p53), we analysed whether celecoxib activated p53 with resultant p53-dependent anti-proliferative effects. Western blot analysis showed that celecoxib enhanced total p53 protein expression in a concentration-dependent manner in U87MG and LN229 cells (Figure 2B). Activation of p53 by celecoxib was verified by translocation of p53 from cytoplasm into nucleus when U87MG cells were treated with celecoxib ( 8 and $30 \mu \mathrm{M}, 18$ hours treatment) compared with untreated controls (Figure 2C).

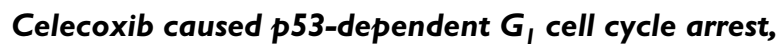 accompanied with $p 21$ activation}

We analysed the human glioblastoma cells to determine whether activation of p53 by celecoxib led to cell cycle arrest. We synchronised glioblastoma cells in serum-free media for 48 hours, with resultant $75.7 \pm 1.6 \%$ of U $87 \mathrm{MG}$ cells and $82.3 \pm 1.7 \%$ of U87MG-E6 cells, being arrested at $G_{0}$ phase. Thereafter, starved cells were released from serum-free condition and treated with celecoxib for 18 hours in medium containing $10 \%$ FBS. Following release from starvation, celecoxib activated p53, as shown by the enhanced total p53 expression in U87MG cells. Addition of PFT inhibited celecoxib-induced p53 expression (Figure $3 \mathrm{~A}$ ). At 18 hours following release from starvation, cell cycle analysis showed that $47.8 \pm 2.7 \%$ of untreated U87MG cells remained in $G_{1}$ phase. Celecoxib (in a concentration-dependent manner) prevented U87MG cells from entering S-phase, resulting in a significantly greater population of cells at $G_{1}$-phase, compared to untreated controls $(P<0.05$, Figure 3B, 3D). There was reciprocal reduction of celecoxib-treated U87MG cells in S- and $\mathrm{G}_{2} \mathrm{M}$-phases, compared to untreated controls.

To establish whether the celecoxib-induced $G_{1}$ cell cycle arrest in U87MG cell was dependent on p53, we analysed the effect of celecoxib ( 8 and $30 \mu \mathrm{M}$ ) on cell cycle progression of U87MG-PFT and U87MG-E6 cells. PFT by itself, prevented U87MG cells from entering S-phase, as demonstrated by the greater population of cells at $\mathrm{G}_{1}$-phase ( 58.7 $\pm 2.3 \%$ ) compared to the population of untreated U87MG cells at $\mathrm{G}_{1}$ phase $(47.8 \pm 2.7 \%$; Figure $3 \mathrm{D})$. PFT $(25 \mu \mathrm{M})$, being a transient and reversible inhibitor of p53, is less efficient in blocking elevated amount of p53 (such as when p53 expression was increased during serum starvation, data not shown), resulting in a greater population of U87MG-PFT cells at $\mathrm{G}_{1}$ phase compared to the population of U87MG cells at $G_{1}$ phase. In parallel, Xu et al. (2005) demonstrated that PFT $(20 \mu \mathrm{M})$ had no effect on cell cycle progression of U87MG cells [40]. Addition of celecoxib to PFT-treated U87MG cells did not affect the cell cycle progression when p53 was inhibited $(P>0.05$, Figure $3 \mathrm{~B}$, $3 D)$, suggesting a p53-dependent celecoxib-induced $G_{1}$ cell cycle arrest in U87MG cells. Continuous inactivation of p53 by E6 in U87MG-E6 cells reduced the proportion of cells at $G_{1}$ phase $(29.5 \pm 3.3 \%)$, compared with the population of U87MG cells at $G_{1}$ phase $(47.8 \pm 2.7 \%)$. This is in accord with the functional role of p53 in arresting cells at $G_{1}$ phase, as was previously shown [41]. Similar to U87MG-PFT cells, celecoxib had no significant effect on U87MG-E6 cell cycle progression $(P>0.05$, Figure 3B, $3 D$ ), thus confirming a p53-mediated $G_{1}$ cell cycle arrest by celecoxib in U87MG glioblastoma cells.

$82.4 \pm 0.9 \%$ of LN229 and $51.0 \pm 3.7 \%$ of U373MG cells were arrested at $\mathrm{G}_{0 / 1}$ phase, following 48 hours of starvation in serum-free media. At 18 hours following treatment (in media containing 10\% FBS), celecoxib prevented LN229 cells from entering S-phase and concentrationdependently increased the percentage population of LN229 cells in $G_{1}$ phase, compared with untreated controls $(P<0.05$, Figure $3 \mathrm{C}, 3 \mathrm{E})$. Celecoxib had no signifi- 


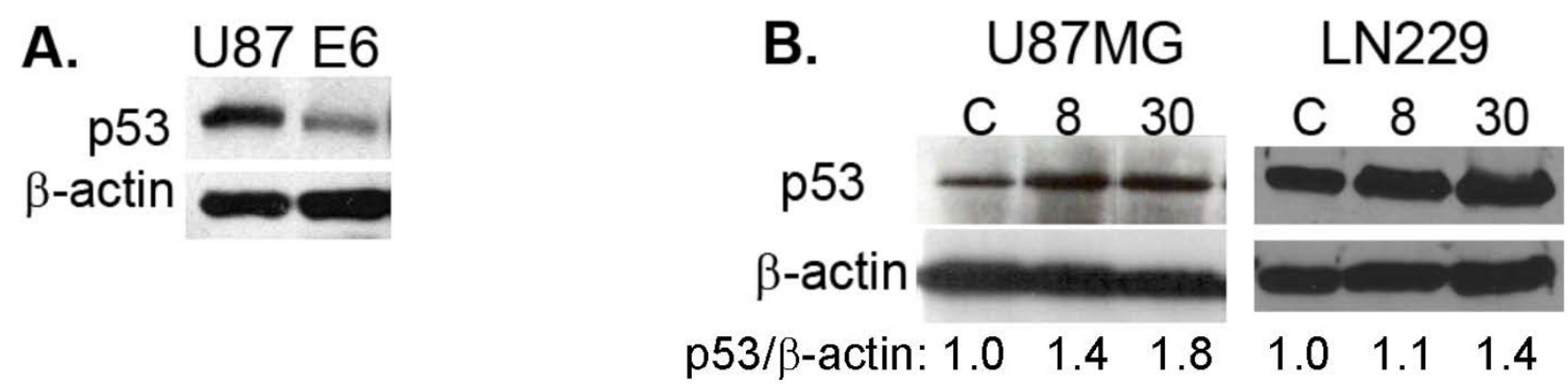

C.
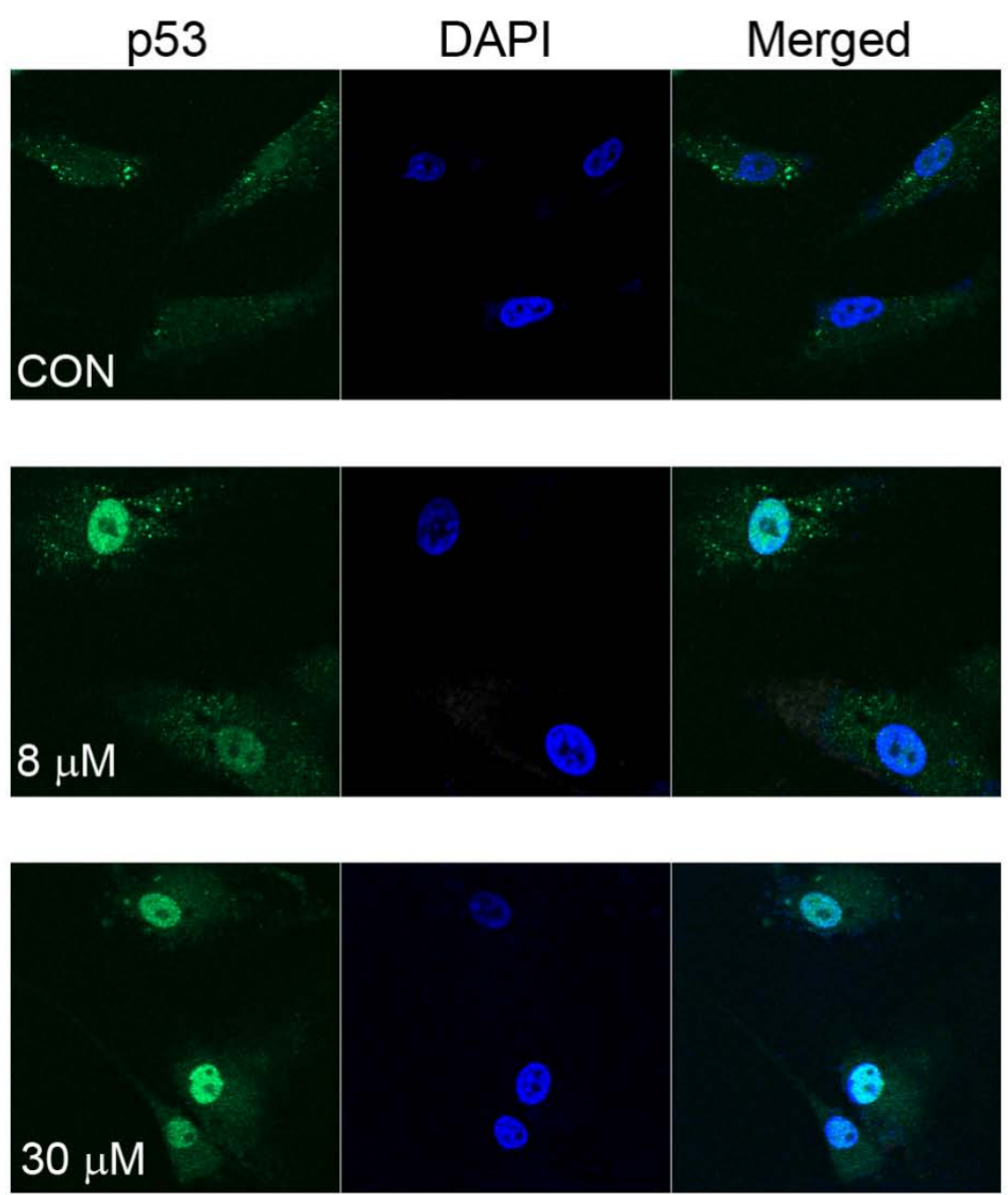

Figure 2

Effect of celecoxib on p53 protein expression and localisation. U87MG and U87MG-E6 cells were analysed for basal p53 expression (A). U87MG and LN229 cells were treated with celecoxib ( 18 hours), followed by immunoblotting for detection of $p 53$. $\beta$-actin was used as loading controls. $p 53$ expression is presented normalised over $\beta$-actin of same samples. $C$, controls; 8 and 30, treated with celecoxib 8 and $30 \mu \mathrm{M}$, respectively $(\mathrm{B}, n=4-5)$. Representative images of celecoxib-treated (I8 hours) U87MG cells immunostained with anti-p53 FITC and DAPI are shown $(C, n=3)$. 
A. Celecoxib $(\mu \mathrm{M})$ : $\quad \begin{array}{lllll}- & 8 & 30 & 8 & 30\end{array}$

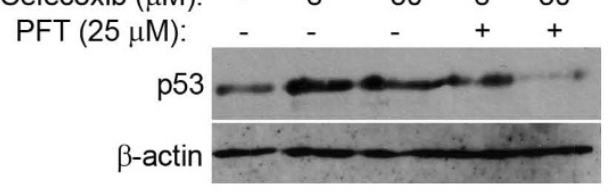

B. U87MG
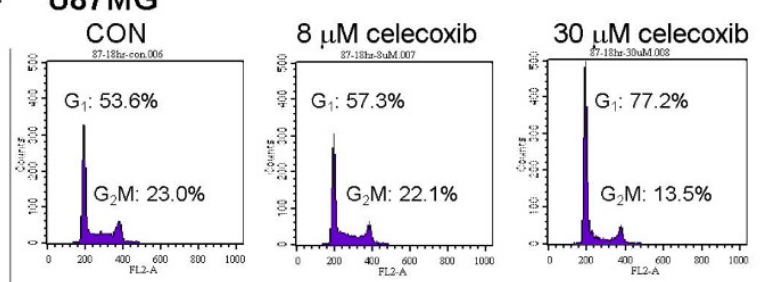

U87MG + PFT
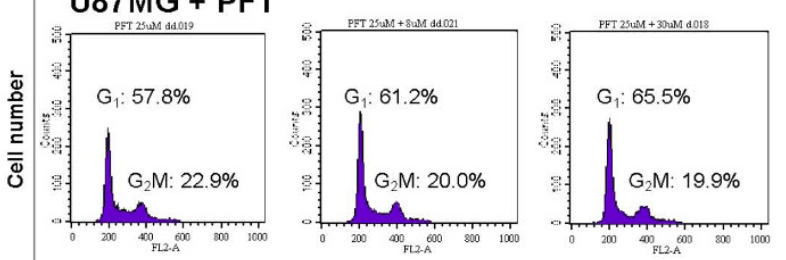

U87MG-E6
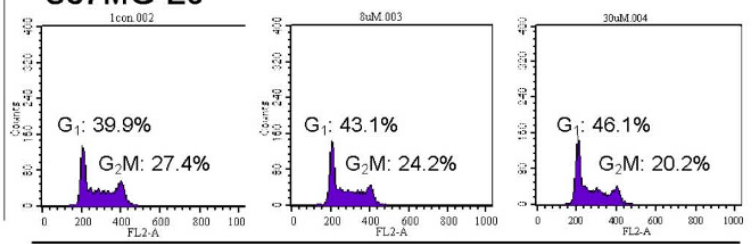

DNA content

\section{D.}

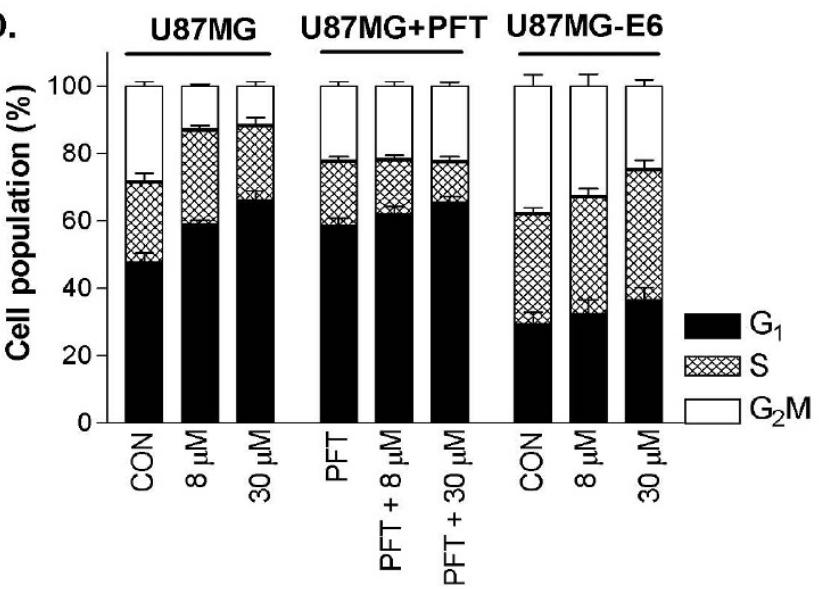

C. LN229
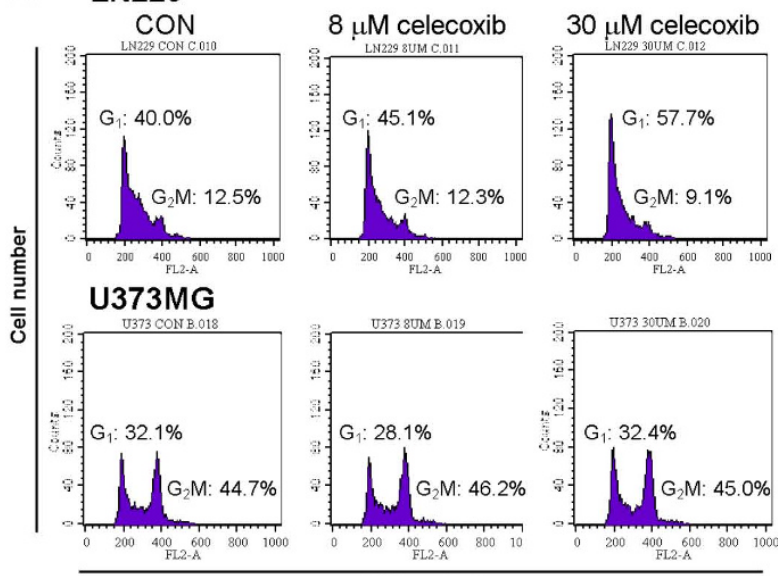

DNA content
E.

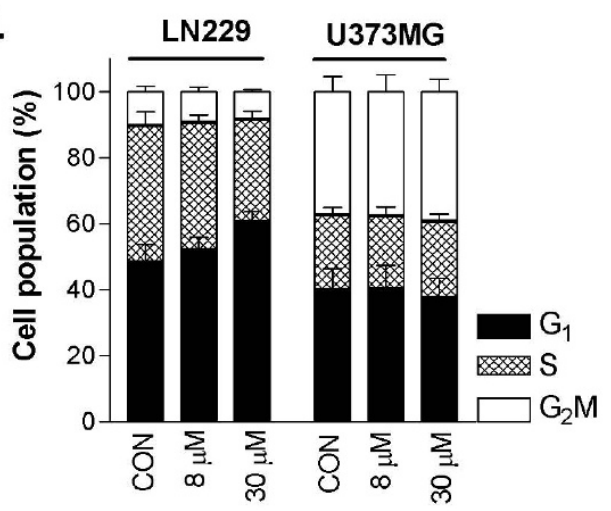

\section{Figure 3}

Effect of celecoxib on p53-dependent cell cycle progression. Cells were synchronised in serum-free medium for 48 hours and then treated with celecoxib $(8$ and $30 \mu \mathrm{M})$ in medium containing 10\% FBS for 18 hours. In some cases, U87MG cells were pre-treated with PFT $(25 \mu \mathrm{M})$ prior to celecoxib treatment. Cells were collected for protein extraction and cell cycle analysis. Following release of cells from starvation, the effect of celecoxib on $\mathrm{p} 53$ protein expression in U87MG and PFTtreated U87MG cells is shown (A). For cell cycle analysis, cells were fixed, stained with propidium iodide and analysed by flow cytometry. Representative histograms of cell cycle progression (B-C) and quantitative analysis of percentage gated cells at $G_{1}$, $S$ and $G_{2} M$ phases (D-E) are shown. All values are expressed as mean \pm S.E.M, $n=5-8$. 
cant effect on cell cycle progression of U373MG cells $(P>$ 0.05 , Figure 3C, 3E). These findings parallel the effect of celecoxib that induces $\mathrm{G}_{1}$ cell cycle arrest in U87MG cells, but not U87MG-E6 or U87MG-PFT cells, thus verifying an induction of p53-dependent $G_{1}$ cell cycle arrest by celecoxib in human glioblastoma cells.

Induction of $\mathrm{G}_{1}$ cell cycle arrest following DNA damage is dependent on up-regulation of CDK inhibitors such as p21, a direct transcriptional target of p53 that is strongly induced by DNA damage in cells expressing wild-type $\mathrm{p} 53$ [42]. We analysed whether p53-dependent $G_{1}$ cell cycle arrest caused by celecoxib was mediated via p21 activation. Under the same synchronised cell condition where celecoxib induced p53-dependent $\mathrm{G}_{1}$ cell cycle arrest, our data showed that celecoxib caused a concentrationdependent increased in p21 mRNA expression in U87MG cells, but not in U87MG-E6 cells where p53 expression was depleted (Figure 4A). We verified these findings by immunocytochemistry, which demonstrated nuclear induction of p21 when U87MG cells were treated with celecoxib (8 and $30 \mu \mathrm{M}$; Figure 4B). In U87MG-E6 cells, celecoxib ( 8 and $30 \mu \mathrm{M}$ ) caused no significant changes in p21 mRNA expression (Figure 4A) and nuclear p21 protein level (Figure 4B). These data suggest that celecoxibinduced p53-dependent $G_{1}$ cell cycle arrest is mediated by p21 activation in U87MG cells.

\section{Celecoxib induced $p 53$-dependent cell autophagy but not apoptosis}

We investigated the functional consequences of celecoxib on programmed cell death type I (apoptosis) and type II (autophagy), whether celecoxib inhibited glioma proliferation by p53-dependent induction of apoptosis or autophagy. In addition to inducing apoptosis, p53 is also known to protect cells from apoptosis and necrotic cell death [43]. As such, inhibition of p53 by PFT and E6 significantly increased the apoptosis level of U87MG-PFT and U87MG-E6 cells, respectively, compared to the basal apoptosis level of U87MG cells $(P<0.05$, Figure 5B). Similarly, the basal apoptosis level of U373MG cells (with mutant p53) was greater than LN229 and U87MG cells (both with functional p53; Figure 5B), as was also shown by others [43]. Regardless of p53 status in the glioma cells, celecoxib ( 8 and $30 \mu \mathrm{M}, 72$ hours treatment) did not cause any significant change in apoptosis population of U87MG, U87MG-PFT, U87MG-E6 and U373MG cells ( $P$ $>0.05$, Figure 5). Celecoxib concentration-dependently increased apoptosis population of LN229 cells, from 2.4 $\pm 0.4 \%$ (controls) to $3.2 \pm 0.5 \%(8 \mu \mathrm{M}, P>0.05)$ and 4.0 $\pm 0.5 \%(30 \mu \mathrm{M} ; P<0.05$, Figure $5 \mathrm{C})$ of total cell population. At 72 hours treatment, celecoxib $(30 \mu \mathrm{M})$ significantly inhibited the survival of LN229 cells to a remaining viable population of $38.9 \pm 7.4 \%$ (see Figure $1 \mathrm{~F} ; P<0.05$, Student's t-test). The small $1.6 \%$ increment in apoptosis level of LN229 cells following 72 hours celecoxib treatment $(30 \mu \mathrm{M})$ suggests apoptosis as a minor mechanism to mediate the anti-proliferative response induced by celecoxib in LN229 cells. The non-significant change in apoptosis level following celecoxib treatment in U87MG, U87MG-PFT, U87MG-E6 and U373MG cells further demonstrates that an alternative major cell death mechanism (such as autophagy) is involved in the anti-proliferative response induced by celecoxib in human glioblastoma cells.

To analyse autophagy, we used acridine orange to stain acidic vesicular organelles (AVOs) that include autophagic vacuoles [44]. In untreated U87MG cells, the cytoplasm and nucleolus fluoresced bright green and dim red. Celecoxib treatment induced the development of AVOs in U87MG cells, as shown by the concentrated fluorescence bright red acidic compartments (Figure 6A). The intensity of red fluorescence is proportional to the degree of acidity and/or volume of the cellular acidic compartment [45]. An increase in the intensity of red fluorescence was observed in U87MG cells treated with increasing concentrations of celecoxib (from 8 to $30 \mu \mathrm{M}$, Figure $6 \mathrm{~A}-\mathrm{B}$ ). When the AVO staining of celecoxib-treated U87MG cells was quantified, we demonstrated that 14.0 $\pm 3.9 \%$ and $18.4 \pm 5.7 \%$ of total cells were significantly stained with acridine orange following celecoxib treatment ( 8 and $30 \mu \mathrm{M}$, respectively), compared with untreated controls $(3.8 \pm 0.0 \% ; P<0.05$, Figure $6 \mathrm{C})$. Inhibition of p53 by PFT significantly induced autophagy of U87MG cells $(P<0.05$, Figure 6C; [46]). Addition of celecoxib had no significant effect on the acridine orange staining of U87MG-PFT cells $(P>0.05$, Figure 6C). In U87MG-E6 cells with reduced level of p53, development of AVOs following celecoxib treatment was not obvious (by microscopic observation, Figure 6A) and statistically non-significant (by FACS analysis; $P>0.05$, Figure 6B, $6 \mathrm{C})$. We verified the celecoxib-induced p53-dependent autophagy in U87MG cells by the changes in expression of light chain 3 (LC3)-II, an autophagosome-specific protein that is recruited to the autophagosome membrane during autophagy [47]. Celecoxib ( 8 and $30 \mu \mathrm{M}$ ) further induced cleavage of LC3 (conversion from LC3-I to LC3-II) in U87MG cells, in parallel with the development of AVOs following celecoxib treatment. Celecoxib ( 8 and $30 \mu \mathrm{M})$ had no effect on the level of LC3-II expression in U87MGPFT and U87MG-E6 cells (Figure 6E).

In LN229 cells (with functional p53), celecoxib (8 and 30 $\mu \mathrm{M}, 72$ hours treatment) significantly induced the development of AVOs $(P<0.05$, Figure $6 \mathrm{D})$, as shown by the significant increased of celecoxib-treated acridine orangestained cells $(14.8 \pm 8.7 \%[8 \mu \mathrm{M}]$ and $19.7 \pm 7.4 \%$ [30 $\mu \mathrm{M}])$, compared with controls $(2.9 \pm 1.8 \%)$. The level of autophagy induction by celecoxib in LN229 cells (4.0-5.8 
A.
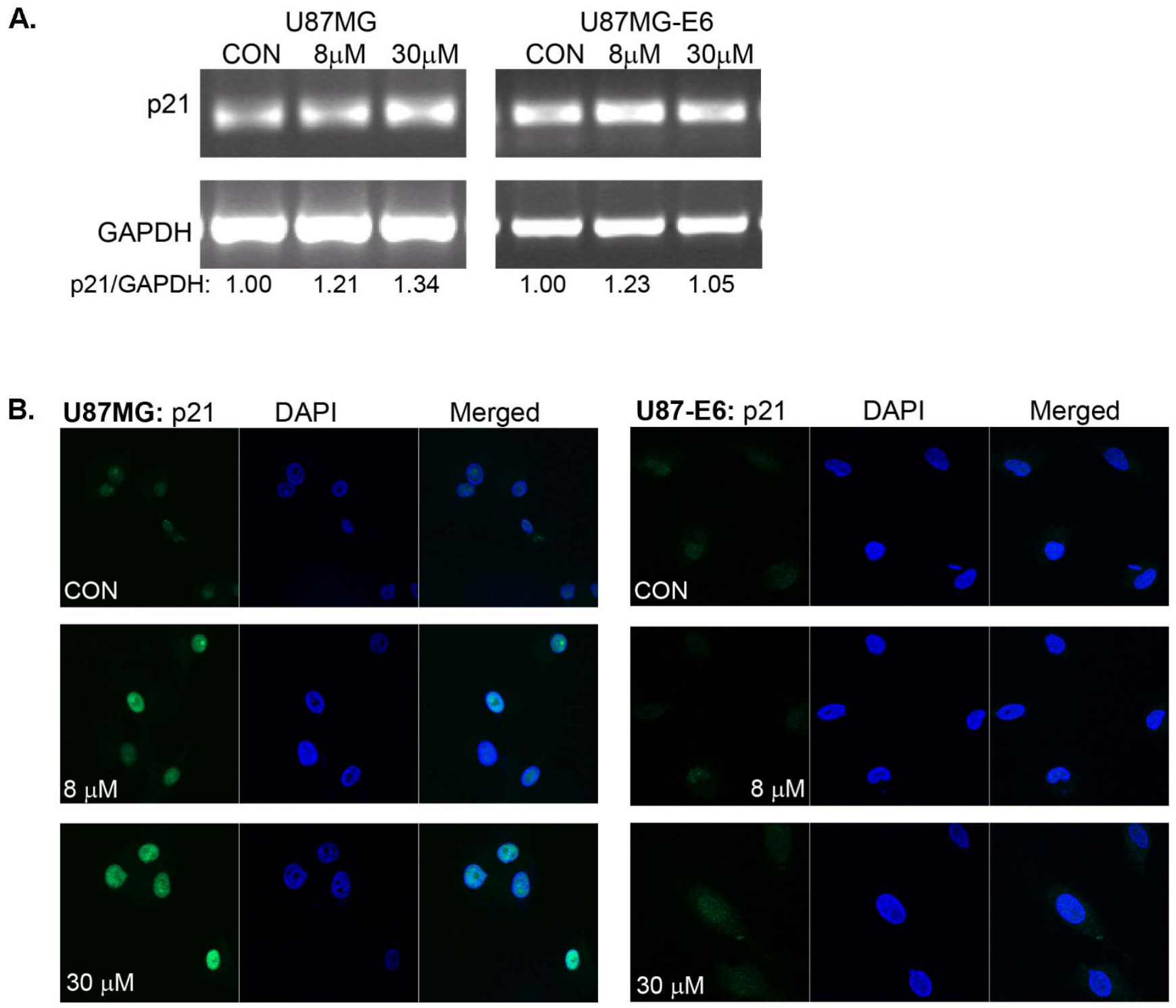

Figure 4

Effect of celecoxib on p2I mRNA expression and protein localisation. Cells were synchronised in serum-free medium for 48 hours and then treated with celecoxib $(8$ and $30 \mu \mathrm{M})$ in medium containing $10 \%$ FBS for 18 hours. Total RNA was extracted from celecoxib-treated cells, followed by RT-PCR using P2I primers. P2I mRNA expression is presented normalised over GAPDH of same samples $(A, n=3-5)$. Representative images of celecoxib-treated cells immunostained with antiP2I FITC and DAPI are shown $(B, n=3)$.

fold of controls) was similar to the extent of autophagy induction in celecoxib-treated U87MG cells, which express functional p53. Celecoxib-induced autophagy response in LN229 cells was supported by the increased expression of LC3-II (Figure 6F). Celecoxib had no significant effect on the development of AVOs, or the level of LC3-II expression in U373MG cells, which contain mutant p53 (Figure 6D, 6F). These findings suggest that celecoxib induced p53-dependent autophagy rather than apoptosis in glioblastoma cells.

\section{Celecoxib induced DNA damage and inhibited DNA synthesis}

To investigate the upstream events preceding p53 activation following celecoxib treatment, we analysed the effect of celecoxib on DNA damage by Comet assays under nondenaturing condition, where induction of comet tails suggests DNA double-strand breaks. Following 5 and 18 hours of treatment, celecoxib ( 8 and $30 \mu \mathrm{M}$ ) significantly increased comet tail moments of U87MG cells $(P<0.05$, Figure 7A). Normalised mean tail moments by celecoxib 

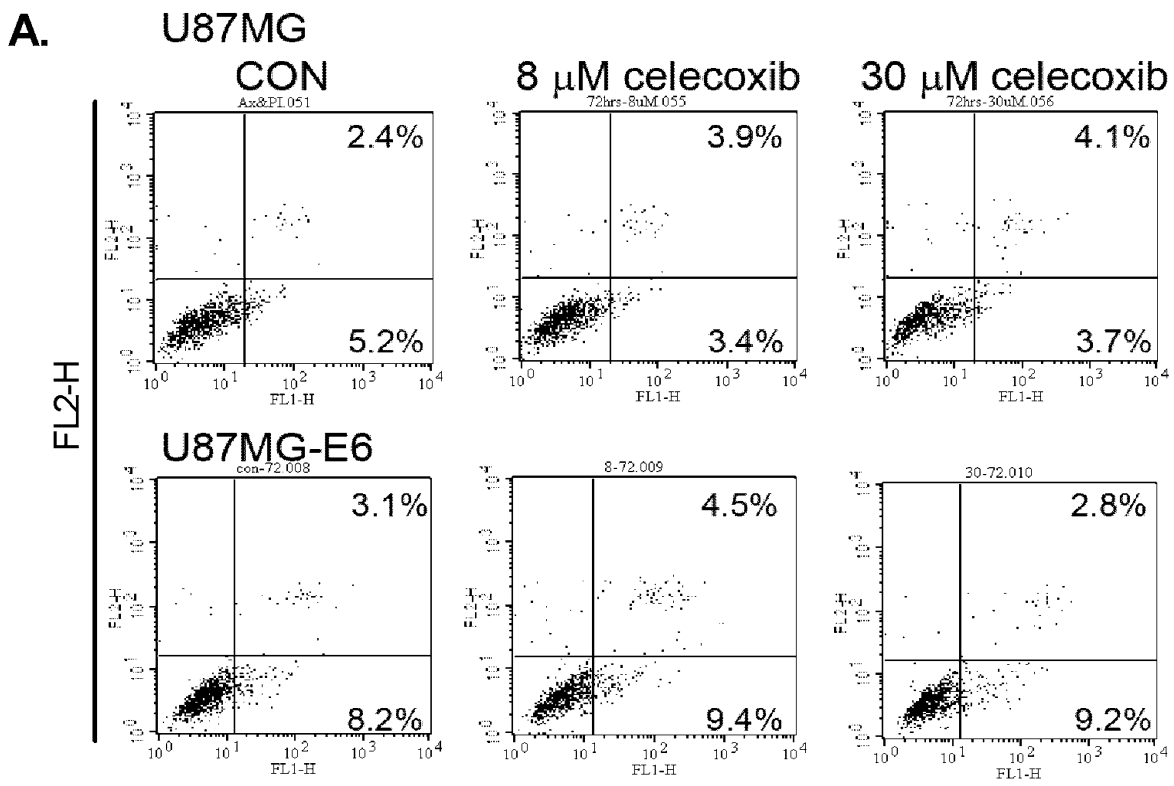

FL1-H

B.

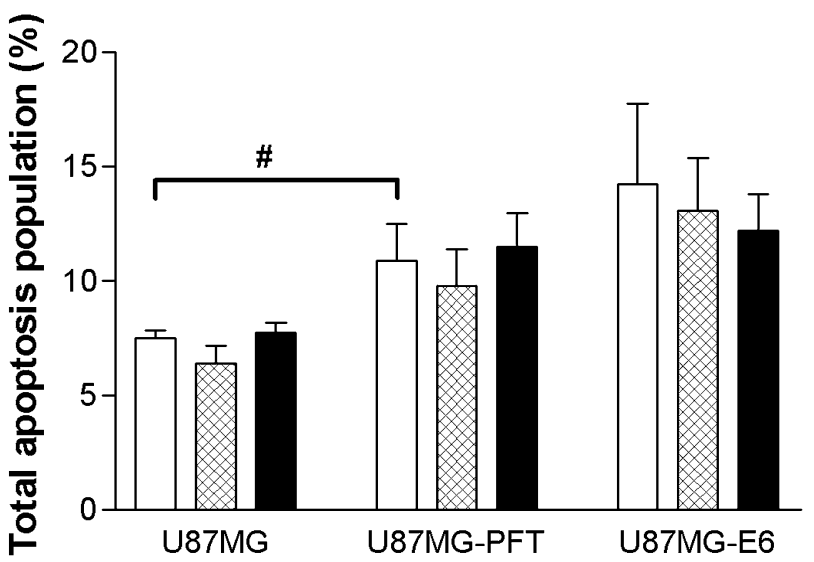

C.

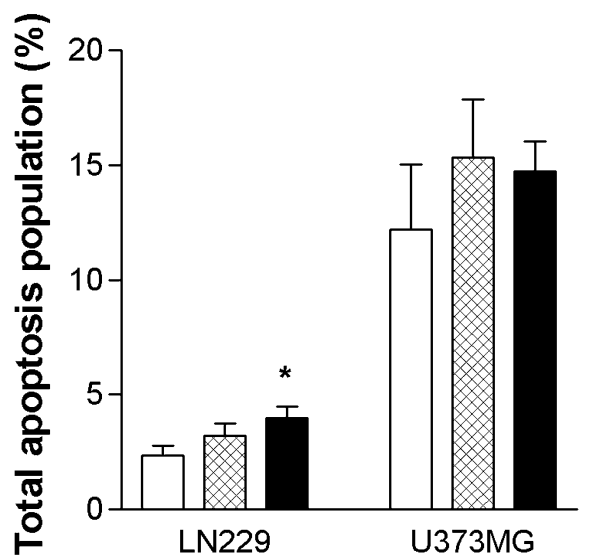

\section{Figure 5}

Effect of celecoxib on cell apoptosis. Cells were treated with celecoxib (8 and $30 \mu \mathrm{M})$ for 72 hours. In some cases, U87MG cells were pre-treated with PFT $(25 \mu \mathrm{M})$ prior to celecoxib treatment. Cells were collected and stained with Annexin V-FITC and propidium iodide, followed by FACS analysis. Percentage population of early apoptosis (lower right quadrant) and late apoptosis (upper right quadrant) in celecoxib-treated U87MG and U87MG-E6 cells, stained with Annexin-FITC and propidium iodide are shown (A). Summary quantitative analyses of total apoptosis population following celecoxib treatment are presented (B-C). Values are expressed as mean \pm S.E.M., $n=3-6$. $* P<0.05$, significantly different from respective controls $(I-$ way ANOVA, Dunnett's test). $\# P<0.05$, significantly different between PFT-treated and -untreated U87MG cells (Mann-Whitney U-test). 
A. U87MG
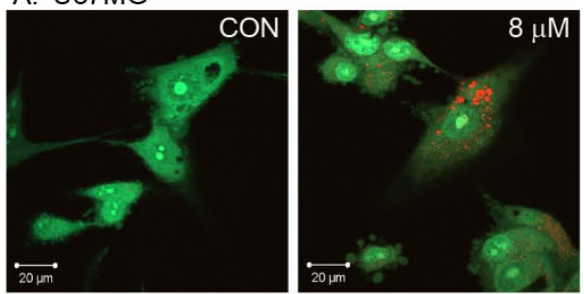

U87MG-E6
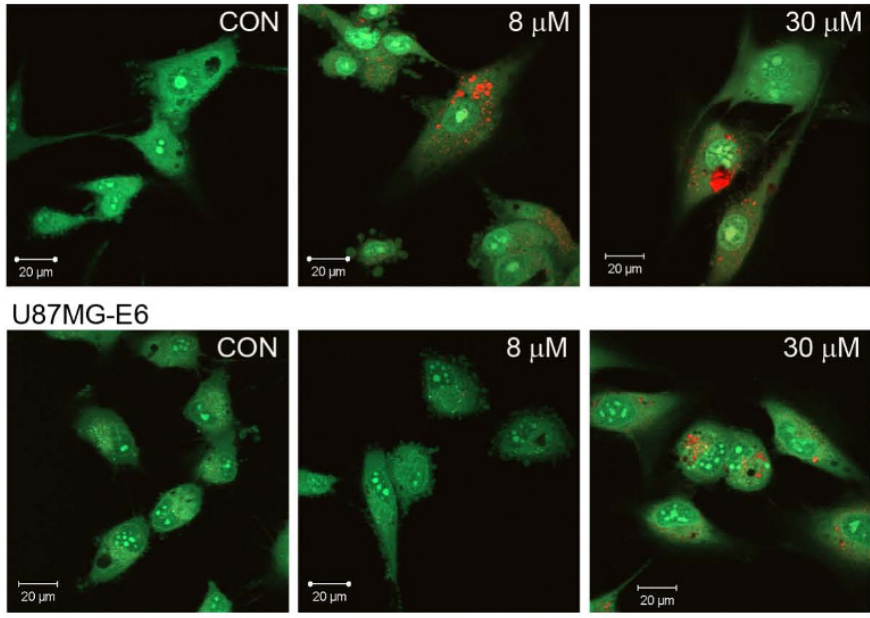

B. U87MG
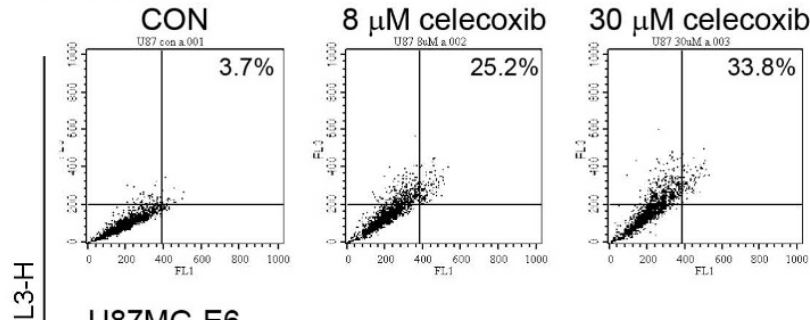

mे

\section{U87MG-E6}
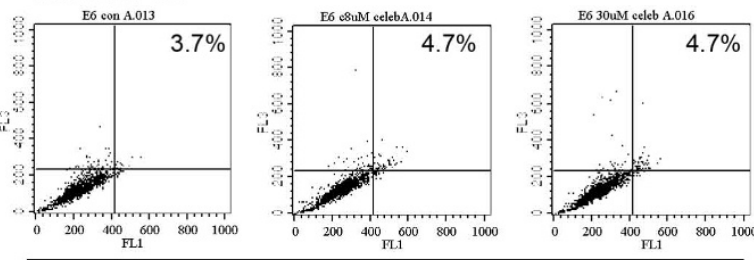

FL1-H

D.

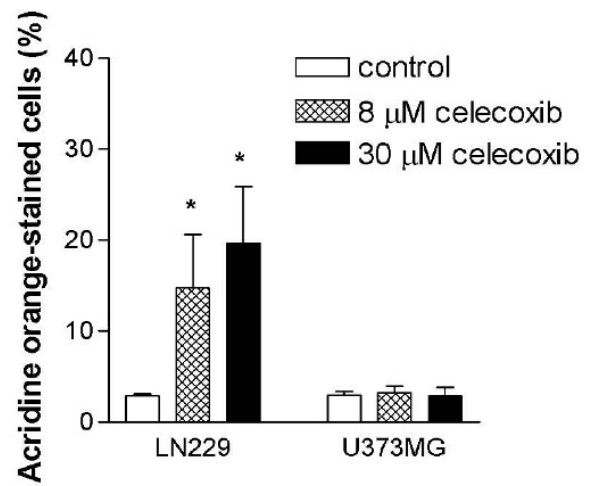

F.

U87MG-E6

E.

U87MG

U87MG+PFT

CON $8 \mu \mathrm{M} 30 \mu \mathrm{M}$

LC3-I

LC3-II

CON $8 \mu \mathrm{M} 30 \mu \mathrm{M}$

CON $8 \mu \mathrm{M} 30 \mu \mathrm{M}$

$\beta$-actin
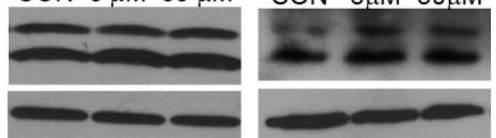

control

$8 \mu \mathrm{M}$ celecoxib

$30 \mu \mathrm{M}$ celecoxib

Figure 6

Effect of celecoxib on p53-dependent autophagy. Cells were treated with celecoxib (8 and $30 \mu \mathrm{M})$ for 72 hours. In some cases, U87MG cells were pre-treated with PFT $(25 \mu \mathrm{M})$ prior to celecoxib treatment. Cells were collected and stained with acridine orange. Representative images of acridine orange-stained celecoxib-treated cells captured by confocal microscopy (A) and analysed by FACS (B) are shown. Summary quantitative analyses of acridine orange-stained cell populations following celecoxib treatment are presented (C-D). Values are expressed as mean \pm S.E.M., $n=3-9$. *P $<0.05$, significantly different from respective controls ( $I$-way ANOVA, Dunnett's test). $\# P<0.05$, significantly different between PFT-treated and -untreated U87MG cells (Mann-Whitney U-test). Protein was extracted from celecoxib-treated (72 hours) cells and analysed for expression of the autophagy marker, LC3. Representative blots of LC3 isoforms LC3-I and LC3-II proteins in celecoxib-treated cells are shown (E-F, $n=3)$. $\beta$-actin was used as loading control.

$(30 \mu \mathrm{M})$ at 5 and 18 hours were $259 \pm 37 \%$ and $372 \pm$ $67 \%$, respectively, of untreated controls (Figure $7 \mathrm{~A}$ ). The effect of celecoxib on DNA synthesis was assessed by incorporation of ${ }^{3} \mathrm{H}$-thymidine into DNA during cellular S-phase. Celecoxib ( 8 and $30 \mu \mathrm{M}, 5$ hours treatment) concentration-dependently inhibited DNA synthesis of
U87MG cells (by $25-36 \%$ vs. controls, $P<0.05$, Figure $7 \mathrm{~B})$, corresponding with celecoxib-induced DNA damage.

\section{Discussion}

Therapeutic targeting of glioblastoma cells with selective COX-2 inhibitors such as celecoxib has demonstrated 


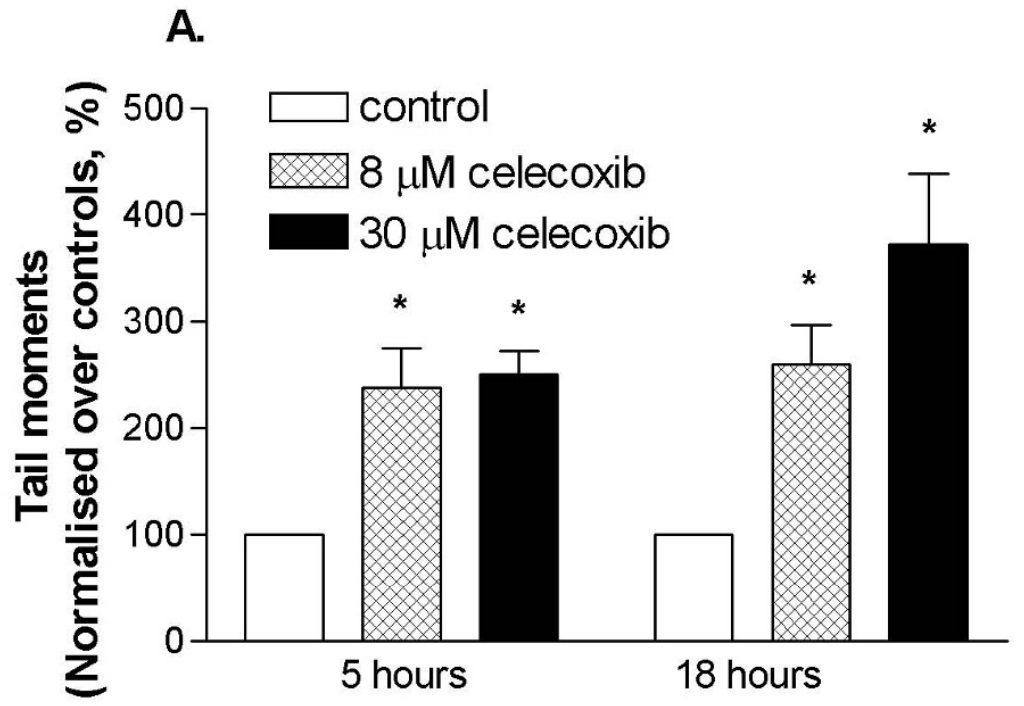

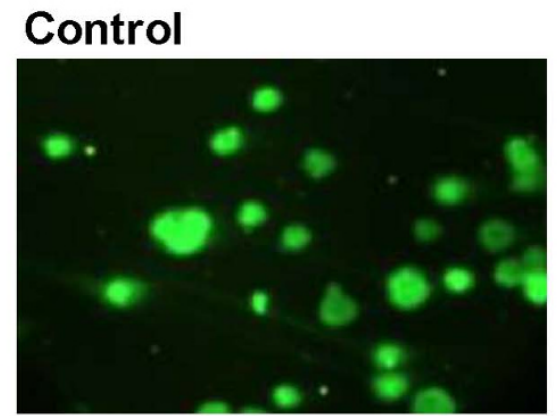
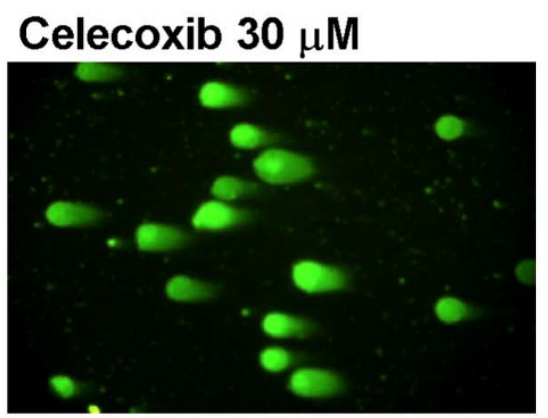

B.

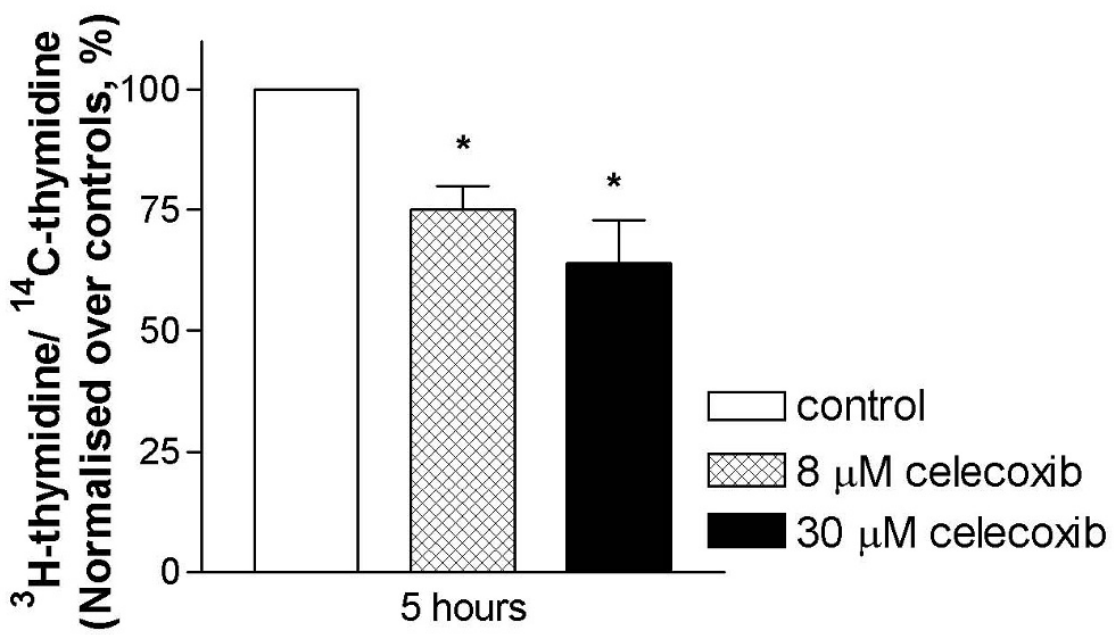

Figure 7

Effect of celecoxib on DNA damage and DNA synthesis. U87MG cells were treated with celecoxib ( 8 and $30 \mu M$ ) and analysed for DNA damage by Comet assays, as shown by representative images and quantitated as comet tail moments $(A, n=$ 5-7). DNA synthesis is presented by incorporation of $\left[{ }^{3} \mathrm{H}\right]$-thymidine/ $\left[{ }^{14} \mathrm{C}\right]$-thymidine in celecoxib-treated cells normalised over controls $(B, n=3-4)$. $* P<0.05$, significantly different from respective controls ( $I$-way ANOVA, Dunnett's test).

potential [4,6-11]. However the underlying anti-proliferative mechanisms of COX-2 inhibitors remain unclear. Understanding the mechanisms underlying the antitumour properties of COX-2 inhibitors is needed for optimisation of therapeutic targeting by COX-2 inhibitors. In this study, we analysed the p53-dependent anti-proliferative effect induced by a selective COX-2 inhibitor, celecoxib in human glioblastoma cells. Our findings demonstrate that celecoxib induced p53-dependent $\mathrm{G}_{1}$ cell cycle arrest followed by autophagy, which are critical for inhibiting growth and proliferation of glioblastoma cells containing functional p53. We demonstrate insensitivity/ resistance of glioblastoma cells to the anti-proliferative effect of celecoxib when p53 expression is inhibited/ 
mutated, but enhanced cytotoxic response of celecoxib when glioblastoma cells express functional p53. Growth inhibition mediated via p53-dependent $[33,34,48]$ and p53-independent $[16,49,50]$ mechanisms have been reported with non-selective and selective COX-2 inhibitors in studies of tumour and non-tumour cells. In brain tumours, this finding is the first to report a p53-dependent anti-glioblastoma effect of a selective COX-2 inhibitor, which supports selective usage of celecoxib in human glioblastomas with functional p53 for enhanced antitumour responses.

p53 is a key molecule in DNA damage response, causing inhibition of cell proliferation by induction of cell cycle arrest, apoptosis/autophagy or senescence. The inhibitory effect of p53 on cell proliferation is due to transcriptional activation of target genes such as p21, GADD45, Bax, DR5 and PUMA [28]. In this study, inhibition of COX-2 by celecoxib [51] activated p53 in human glioblastoma U87MG cells, as demonstrated by translocation of p53 from cytoplasm to nucleus accompanied with accumulation of total p53 expression. In line with our study, activation of $\mathrm{p} 53$ by COX inhibitors has also been demonstrated in colon and oral cancer cells $[33,34,52]$. We investigated whether celecoxib-induced p53 activation is followed by cell cycle arrest, apoptosis or autophagy in human glioblastoma cells. One study demonstrated a tumour cell-type dependent effect of cell cycle arrest and apoptosis following celecoxib treatment. Liu and colleagues (2003) reported that celecoxib-induced DNA damage led to $\mathrm{G}_{2} \mathrm{M}$ cell cycle arrest in mammary (and not lung) cancer, but apoptosis in lung (and not mammary) cancer cells [26]. The underlying mechanisms for these differential celecoxib-induced functional responses were not addressed. Our study in human glioblastoma cells reveal that celecoxib-induced p53 activation is followed by p53-dependent $G_{1}$ cell cycle arrest and p21 activation. Celecoxib-induced $G_{1}$ cell cycle arrest accompanied by increased p21 protein expression has been reported in human cholangiocarcinoma [12], colorectal $[13,17]$, hepatocellular [35] and prostate cancer cells [14].

While apoptosis is considered a major anti-proliferative mechanism of celecoxib $[9,13-15,17,26]$, our findings show that induction of $p 53$-dependent $G_{1}$ cell cycle arrest by celecoxib is followed by p53-dependent cell autophagy and not apoptosis. It should be noted that higher concentrations of celecoxib $(40-100 \mu \mathrm{M})$ induce apoptosis $[9,13-15,17,26]$. The celecoxib concentrations $(40-100$ $\mu \mathrm{M}$ ) are 4 to 11 -fold greater than $8 \mu \mathrm{M}$, the human plasma concentration of celecoxib after consumption of $800 \mathrm{mg} /$ $\mathrm{kg}$ per day [39] and the concentration that is presently used in this study. Mazzanti et al. (2009) recently showed that celecoxib (10 and $20 \mu \mathrm{M})$ induces apoptosis, but lower concentrations of celecoxib (at 2.5 and $5 \mu \mathrm{M}$ ) induce autophagy in hepatocellular carcinoma cells that are cultured in serum-free medium [35]. The sensitivity of tumour cells to celecoxib-induced cellular apoptosis or autophagy is likely to be concentration- or tumour typedependent. The role of p53 in autophagy remains controversial with studies suggesting activation of $\mathrm{p} 53$, as well as inhibition of p53, as inductive of autophagy [46]. In our study, induction of autophagy by celecoxib in glioblastoma cells is p53-dependent, as shown by the autophagy induction only in celecoxib-treated glioblastoma cells with high (and not low) functional level of p53. In contrast, Mazzanti et al. (2009) reported that induction of autophagy by celecoxib ( 2.5 and $5 \mu \mathrm{M})$ is mediated by Pglycoprotein and $\mathrm{Bcl} 2$ via a $\mathrm{p} 53$-independent mechanism. The role of autophagy in cancer development is complex, as it has been implicated in both tumour survival and tumour cell death [53]. Induction of cell cycle arrest preceding autophagy induction inhibits tumor growth [54]. Our results support the induction of p53-dependent $G_{1}$ cell cycle arrest, followed by autophagy as a mechanism for celecoxib to prevent glioma cell survival. Induction of p53-dependent autophagy independent of apoptosis should be considered as one of the underlying anti-proliferative mechanisms of COX-2 inhibitors, celecoxib in particular, in various tumours.

We investigated the 'up-stream' mechanisms preceding p53 activation in U87MG cells treated with celecoxib. We found that celecoxib ( 8 and $30 \mu \mathrm{M}$ ) induced DNA damage, accompanied with inhibition of DNA synthesis in U87MG cells, which led to p53-induced $\mathrm{G}_{1}$ cell cycle arrest and autophagy events. These findings of celecoxibinduced DNA damage followed by p53-dependent $G_{1}$ cell cycle arrest and autophagy are clinically relevant since low concentration of celecoxib $(8 \mu \mathrm{M})$ are attainable in human serum [39]. In cancer cells, DNA damage was induced following celecoxib treatment (at high concentrations of 50 and $100 \mu \mathrm{M}$ ) in murine lung (A549) and mammary (MCa-35) cancer cells [26], and by the nonselective COX inhibitor aspirin in HT-29 human colon carcinoma [25]. Activation of DNA damage-p53 signalling by COX-2 inhibitors has not been reported. One study proposes induction of DNA damage by the COX inhibitor R-flurbiprofen following the observation that Rflurbiprofen increases p53 (Ser 15) phosphorylation in colon cancer cells, but this has yet to be verified [33]. Our study demonstrates that selective COX-2 inhibition by celecoxib induces DNA damage and inhibits DNA synthesis, resulting in p53 activation and subsequent anti-proliferative effects in glioblastoma cells. The mechanisms underlying celecoxib-induced DNA damage remain unclear and are beyond the scope of this study. Whilst inhibition of COX-2 expression is reported to reduce generation of reactive oxygen species and prevent DNA damage, recent studies show that COX-2 inhibitors celecoxib 
[55] and sulindac [56], induce reactive oxygen species to mediate anti-tumour responses. Seo et al. (2007) also showed that induction of reactive oxygen species by sulindac was accompanied by phosphorylation of p53 (Ser 15) and accumulation of p53 in human multiple myeloma cells [56]. It is possible that celecoxib induces reactive oxygen species, followed by activation of DNA damage-p53 signalling to mediate anti-glioblastoma effects, but this requires further investigation.

\section{Conclusion}

Our study reveals an important underlying mechanism of celecoxib-mediated inhibition of glioblastoma cell growth, by induction of DNA damage leading to p53dependent $G_{1}$ cell cycle arrest and autophagy, but not apoptosis. These results highlight the importance of $\mathrm{p} 53$ for enhanced anti-glioblastoma response by celecoxib. With the clinical relevant concentration of celecoxib used in this study, the present findings support potential clinical application of celecoxib to improve therapy of glioblastoma multiforme patients.

\section{Methods}

\section{Cell culture and drug treatment}

Human glioblastoma cells U87MG, U373MG, LN229 (American Type Culture Collection, Rockville, MD) and U87MG-E6 (U87MG cells transfected with human papillomavirus E6 oncoprotein, kindly provided by Russell O. Pieper, UCSF Comprehensive Cancer Centre, San Francisco, CA) were grown in Dulbecco's modified Eagle's medium (DMEM) supplemented with fetal bovine serum (FBS, 10\%), nonessential amino acids $(100 \mu \mathrm{M})$, sodium pyruvate $(1 \mathrm{mM})$, streptomycin $(100 \mu \mathrm{g} / \mathrm{ml})$ and penicillin $\left(100 \mathrm{U} / \mathrm{ml}\right.$, Gibco BRL, Grand Island, NY) at $37^{\circ} \mathrm{C}$ in an atmosphere containing $5 \% \mathrm{CO}_{2}$.

Celecoxib (Pfizer Pharmacia, New York, NY) and pifithrin- $\alpha$ (PFT, Sigma, St. Louis, MO) was prepared as 100 $\mathrm{mg} / \mathrm{ml}$ and $10 \mathrm{mg} / \mathrm{ml}$ stock in dimethyl sulfoxide (DMSO; Sigma), respectively. Stock solutions were diluted to required concentrations with culture medium on the day of treatment. U87MG cells were treated with PFT (U87MG-PFT) for 30 minutes prior to celecoxib treatment. Vehicle DMSO was used as drug replacement in experimental controls. The final DMSO concentration did not exceed $0.15 \%(\mathrm{v} / \mathrm{v})$. All experiments were performed in accordance with guidelines approved by the Institutional Review Board of National Cancer Centre, Singapore.

\section{Cell viability assay}

In 96-well plates, cells were treated with increasing concentrations of celecoxib to identify dose-dependent viability of U87MG, U87MG-E6, U87MG-PFT, LN229 and U373MG cells. In some cases, U87MG cells were pre- treated with PFT ( $25 \mu \mathrm{M})$ for 30 minutes prior to celecoxib treatment. After 24 and 72 hours, cells were stained with 3-(4,5-dimethylthiazol-2-yl)-2,5-diphenyltetrazolium bromide (MTT, $1 \mathrm{mg} / \mathrm{ml}$ ), incubated for 4 hours at $37^{\circ} \mathrm{C}$, lysed with lysis buffer (N, N-dimethyl formamide, 50\%; sodium dodecyl sulphate, 20\%) and absorbance measured at $570 \mathrm{~nm}$. Readings of celecoxib-treated cells were normalised against DMSO-treated controls.

\section{Western blot analysis}

Cells treated with DMSO or celecoxib ( 8 and $30 \mu \mathrm{M}$ ) were lysed and protein quantitated by Bradford assays (Bio-Rad Laboratories, Hercules, CA). Equal amounts of protein were separated in SDS-polyacrylamide gels and transferred onto nitrocellulose membranes (Amersham Biosciences). Membranes were blocked with 5\% skim milk, incubated overnight $\left(4^{\circ} \mathrm{C}\right)$ with monoclonal anti-p53 (DO-1, 1:500, Santa Cruz Biotechnology, Santa Cruz, CA) or rabbit polyclonal anti-LC3 (1:500, Santa Cruz Biotechnology), followed by horseradish peroxidase-conjugated secondary antibodies (Amersham Biosciences). Protein bands were visualised with ECL plus chemiluminescence kit (Amersham Biosciences). For loading controls, membranes were stripped and re-probed with horseradish peroxidase-conjugated anti- $\beta$-actin (Santa Cruz Biotechnology).

\section{Immunocytochemistry}

Celecoxib-treated $(0,8$ and $30 \mu \mathrm{M})$ cells (grown on cover slips) were fixed and permeabilised in $0.2 \%$ Triton X-100. After wash, cells were blocked with 5\% BSA, incubated with specific antibodies against p53 (1:50, Neomarkers, Fremont, CA) or p21 (1:100, Santa Cruz Biotechnology) for 1 hour at room temperature, followed by incubation with anti-mouse FITC-conjugated secondary antibodies (1:200, Molecular Probes). Cover slips were mounted with VectaShield Mounting Medium containing DAPI (Vecta Laboratories, Burlingame, CA). Images were viewed under a Laser Scanning Microscope and images captured using software LSM510 (Zeiss, Germany).

\section{Cell cycle analysis and p2 I mRNA expression}

Cells were synchronised at $G_{0}$ phase in serum-free medium for 48 hours, followed by celecoxib treatment $(0$, 8 and $30 \mu \mathrm{M}$ ) in medium containing 10\% FBS for 18 hours. In some cases, U87MG cells were pre-treated with PFT $(25 \mu \mathrm{M})$ for 30 minutes prior to celecoxib treatment. For cell cycle analysis, collected cells were fixed overnight with ice-cold ethanol (75\%), stained with propidium iodide $(5 \mu \mathrm{g} / \mathrm{ml}$, Sigma) supplemented with $100 \mu \mathrm{g} / \mathrm{ml}$ RNase (Sigma), and then analysed with flow cytometry using CellQuest Pro (BD Biosciences, San Jose, CA) for 10,000 events. For p21 mRNA analysis, total RNA was extracted from celecoxib-treated cells with Tri-Reagent (Molecular Research Centre, Cincinnati, OH). $1 \mu \mathrm{g}$ total 
RNA was reverse transcribed using the ImProm-II Reverse Transcription system (Promega Corporation, Madison, WI). PCR was performed with specific primers for p21 (forward: 5'-CAGCATGACAGATTTCTACCAC-3', reverse: 5'-CCAGGGTATGTACATGAGGAG-3') and GAPDH (forward: 5'-GGAAGGTGAAGGTCGGAGTC-3', reverse: 5'GTCTTCTGGGTGGCAGTGAT-3') at the following conditions: $94^{\circ} \mathrm{C}, 55^{\circ} \mathrm{C}$ and $72^{\circ} \mathrm{C}$ at 30 seconds each temperature for 30 cycles.

\section{Apoptosis and autophagy assays}

Cells were treated with DMSO or celecoxib ( 8 and $30 \mu \mathrm{M}$ ) for 72 hours. In some cases, U87MG cells were pre-treated with PFT $(25 \mu \mathrm{M})$ for 30 minutes prior to celecoxib treatment. For apoptosis assays, trypsinised cells were incubated with FITC-conjugated Annexin V (BD Biosciences) and propidium iodide $(5 \mu \mathrm{g} / \mathrm{ml})$. 10,000 events were analysed for apoptosis by FACS with CellQuest Pro software. For autophagy assays, celecoxib-treated cells were stained with acridine orange $(1 \mu \mathrm{g} / \mathrm{ml}$, Sigma $)$ for $15 \mathrm{mins}$ at $37^{\circ} \mathrm{C}$. Trypsinised cells were re-suspended in phenol redfree growth media (Gibco BRL) and 10,000 events were analysed by FACS with CellQuest Pro software. Acridine orange-stained cells grown on cover slips were viewed under a Laser Scanning Microscope and images captured using software LSM510.

\section{Comet assays and ${ }^{3} \mathrm{H}$-thymidine incorporation assays}

DNA damage was analysed by Comet assays as follows: Sub-confluent cells were treated with DMSO or celecoxib ( 8 and $30 \mu \mathrm{M}$ ) for 5 and 18 hours. Cells were mixed with $0.5 \%$ low melting point agarose and allowed to solidify on slides. Slides were immersed in lysis buffer, electrophoresis in tris-base buffer, stained with SYBR Green 1 (Trevigen, Gaithersburg, MD) and analysed with fluorescence microscopy. DNA damage, characterised by formation of comet tails, was quantitated by tail moments (multiplication of DNA tail migration from cell nucleus with DNA content) using Comet Score Freeware (Tritek Corporation, Summerduck, VA).

DNA synthesis was quantified with ${ }^{3} \mathrm{H}$-thymidine incorporation assays as follows: Sub-confluent cells were labeled with [methyl- $\left.{ }^{14} \mathrm{C}\right]$-thymidine (Amersham Biosciences, Buckinghamshire, UK) overnight, followed by celecoxib treatment ( 8 and $30 \mu \mathrm{M}, 5$ hours). After wash, cells were incubated with medium containing [methyl${ }^{3} \mathrm{H}$ ]-thymidine (Amersham Biosciences) for 20 minutes, followed by $5 \%$ trichloroacetic acid and then $100 \%$ ethanol. Cells were air-dried, lysed in 1\% sodium dodecyl sulphate and $10 \mathrm{mM} \mathrm{NaOH}$, and subsequently the radioactivity measured with a liquid scintillation counter (Wallac, Turku, Finland). A control sample labelled with [methyl- ${ }^{14} \mathrm{C}$ ]-thymidine alone was included to determine [methyl-14 C]-thymidine signal spillover into [methyl-3 $\mathrm{H}$ ]- thymidine channel. DNA synthesis was presented as a percentage of [methyl-33]-thymidine/[methyl-14 $\mathrm{C}]$-thymidine ratio in celecoxib-treated cells over controls.

\section{Statistical analysis}

All values are presented as mean \pm standard error of mean (S.E.M.) and $n$ indicates number of independent experiments. The concentration-dependent effect of celecoxib on viability of glioblastoma cells was analysed by 2-way analysis of variance (2-way ANOVA). The effect of celecoxib on DNA damage, DNA synthesis, cell cycle progression, autophagy and cell apoptosis were analysed by 1-way ANOVA, followed by Dunnett's test (control vs. celecoxib, 8 or $30 \mu \mathrm{M}$ ). The effect of PFT on cell apoptosis and autophagy in U87MG cells was analysed by MannWhitney U-test. A $P$ value of less than 0.05 was considered to be significant. GB-STAT (Dynamic Microsystems, Silver Springs, MD) statistical package was used in all calculations.

\section{Abbreviations}

ANOVA: analysis of variance; AVO: acidic vesicular organelle; BSA: bovine serum albumin; COX-2: cyclooxygenase-2; DMSO: dimethyl sulfoxide; FBS: fetal bovine serum; FDA: Food and Drug Administration; LC3: light chain-3; PFT: pifithrin- $\alpha$.

\section{Competing interests}

The authors declare that they have no competing interests.

\section{Authors' contributions}

KBK, SKY and QHG performed the experiments. KBK drafted the manuscript, analysed and interpreted the experimental findings. KBK and ZCJ conceived the study and participated in experimental concept and design. KBK, ZCJ and WMC wrote the final version of manuscript. All authors read and approved the final manuscript.

\section{Acknowledgements}

The authors would like to thank A/Prof. Russell Pieper (UCSF Comprehensive Cancer Centre, San Francisco, CA) for providing the stable transfectant U87MG-E6 cells, and Yin Ling Wong for technical assistance in performing part of the cell viability assays. This study was supported by a grant from Singhealth Foundation, Singapore (SHF/FG023/2004). K.B. Kang was a recipient of the Post-doctoral Research Fellowship from the Singapore Millennium Foundation, Singapore.

\section{References}

I. Stupp R, Mason WP, Bent MJ van den, Weller M, Fisher B, Taphoorn MJ, Belanger K, Brandes AA, Marosi C, Bogdahn U, Curschmann J, Janzer RC, Ludwin SK, Gorlia T, Allgeier A, Lacombe D, Cairncross JG, Eisenhauer E, Mirimanoff RO, European Organisation for Research and Treatment of Cancer Brain Tumor and Radiotherapy Groups, National Cancer Institute of Canada Clinical Trials Group: Radiotherapy plus concomitant and adjuvant temozolomide for glioblastoma. N Engl J Med 2005, 352:987-996.

2. Marnett LJ, Rowlinson SW, Goodwin DC, Kalgutkar AS, Lanzo CA: Arachidonic acid oxygenation by COX-I and COX-2. Mech- 
anisms of catalysis and inhibition. J Biol Chem 1999, 274:22903-22906.

3. Deininger MH, Weller M, Streffer J, Mittelbronn M, Meyermann R: Patterns of cyclooxygenase- $I$ and $\mathbf{- 2}$ expression in human gliomas in vivo. Acta Neuropathol (Berl) 1999, 98:240-244.

4. Joki T, Heese O, Nikas DC, Bello L, Zhang J, Kraeft SK, Seyfried NT, Abe T, Chen LB, Carroll RS, Black PM: Expression of cyclooxygenase 2 (COX-2) in human glioma and in vitro inhibition by a specific COX-2 inhibitor, NS-398. Cancer Res 2000, 60:4926-4931.

5. Shono T, Tofilon PJ, Bruner JM, Owolabi O, Lang FF: Cyclooxygenase-2 expression in human gliomas: prognostic significance and molecular correlations. Cancer Res 200I, 6 I:4375-438I.

6. Petersen C, Petersen S, Milas L, Lang FF, Tofilon PJ: Enhancement of intrinsic tumor cell radiosensitivity induced by a selective cyclooxygenase-2 inhibitor. Clin Cancer Res 2000, 6:2513-2520.

7. Matsuo M, Yonemitsu N, Zaitsu M, Ishii K, Hamasaki Y, Fukuyama K, Tabuchi K, Miyazaki S: Expression of prostaglandin H synthase2 in human brain tumors. Acta Neuropathol (Berl) 200I, 102: $181-187$.

8. Kardosh A, Blumenthal M, Wang WJ, Chen TC, Schonthal AH: Differential effects of selective COX-2 inhibitors on cell cycle regulation and proliferation of glioblastoma cell lines. Cancer Biol Ther 2004, 3:55-62.

9. Nam DH, Park K, Park C, Im YH, Kim MH, Lee S, Hong SC, Shin HJ, $\mathrm{Kim} \mathrm{JH}$, Eoh W, McDonnell TJ: Intracranial inhibition of glioma cell growth by cyclooxygenase-2 inhibitor celecoxib. Oncol Rep 2004, II:263-268.

10. Portnow J, Suleman S, Grossman SA, Eller S, Carson K: A cyclooxygenase-2 (COX-2) inhibitor compared with dexamethasone in a survival study of rats with intracerebral $9 \mathrm{~L}$ gliosarcomas. Neuro Oncol 2002, 4:22-25.

11. Levin VA, Giglio P, Puduvalli VK, Jochec J, Groves MD, Yung WK Hess K: Combination chemotherapy with I3-cis-retinoic acid and celecoxib in the treatment of glioblastoma multiforme. J Neurooncol 2006, 78:85-90.

12. Han C, Leng J, Demetris AJ, Wu T: Cyclooxygenase-2 promotes human cholangiocarcinoma growth: evidence for cyclooxygenase-2-independent mechanism in celecoxib-mediated induction of $\mathrm{p} 2 \mathrm{I}$ wafl/cip I and p27kip I and cell cycle arrest. Cancer Res 2004, 64:1369-1376.

13. Maier TJ, Schilling K, Schmidt R, Geisslinger G, Grosch S: Cyclooxygenase-2 (COX-2)-dependent and -independent anticarcinogenic effects of celecoxib in human colon carcinoma cells. Biochem Pharmacol 2004, 67:| 469-1478.

14. Narayanan BA, Condon MS, Bosland MC, Narayanan NK, Reddy BS: Suppression of N-methyl-N-nitrosourea/testosteroneinduced rat prostate cancer growth by celecoxib: effects on cyclooxygenase-2, cell cycle regulation, and apoptosis mechanism(s). Clin Cancer Res 2003, 9:3503-3513.

15. Arico S, Pattingre S, Bauvy C, Gane P, Barbat A, Codogno P, OgierDenis $E$ : Celecoxib induces apoptosis by inhibiting 3-phosphoinositide-dependent protein kinase-I activity in the human colon cancer HT-29 cell line. J Biol Chem 2002, 277:276 I 3-2762I.

16. Dvory-Sobol H, Cohen-Noyman E, Kazanov D, Figer A, Birkenfeld S, Madar-Shapiro L, Benamouzig R, Arber N: Celecoxib leads to G2 $M$ arrest by induction of $\mathrm{p} 2 \mathrm{I}$ and down-regulation of cyclin B I expression in a p53-independent manner. Eur J Cancer 2006, 42:422-426.

17. Grosch S, Tegeder I, Niederberger E, Brautigam L, Geisslinger G: COX-2 independent induction of cell cycle arrest and apoptosis in colon cancer cells by the selective COX-2 inhibitor celecoxib. Faseb J 200 I, I 5:2742-2744.

18. Masferrer IL, Leahy KM, Koki AT, Zweifel BS, Settle SL, Woerner BM, Edwards DA, Flickinger AG, Moore RJ, Seibert K: Antiangiogenic and antitumor activities of cyclooxygenase-2 inhibitors. Cancer Res 2000, 60:1306-1311.

19. Milas L, Furuta Y, Hunter N, Nishiguchi I, Runkel S: Dependence of indomethacin-induced potentiation of murine tumor radioresponse on tumor host immunocompetence. Cancer Res 1990, 50:4473-4477.

20. Shiff SJ, Rigas B: The role of cyclooxygenase inhibition in the antineoplastic effects of nonsteroidal antiinflammatory drugs (NSAIDs). J Exp Med 1999, 190:445-450.

21. Lee SH, Williams MV, Dubois RN, Blair IA: Cyclooxygenase-2 mediated DNA damage. J Biol Chem 2005, 280:28337-28346.
22. Hsu CS, Li Y: Aspirin potently inhibits oxidative DNA strand breaks: implications for cancer chemoprevention. Biochem Biophys Res Commun 2002, 293:705-709.

23. Tardieu D, Jaeg JP, Deloly A, Corpet DE, Cadet J, Petit CR: The COX-2 inhibitor nimesulide suppresses superoxide and 8hydroxy-deoxyguanosine formation, and stimulates apoptosis in mucosa during early colonic inflammation in rats. Carcinogenesis 2000, 21:973-976.

24. Matthias C, Schuster MT, Zieger S, Harreus U: COX-2 inhibitors celecoxib and rofecoxib prevent oxidative DNA fragmentation. Anticancer Res 2006, 26:2003-2007.

25. Qiao L, Hanif R, Sphicas E, Shiff SJ, Rigas B: Effect of aspirin on induction of apoptosis in HT-29 human colon adenocarcinoma cells. Biochem Pharmacol 1998, 55:53-64.

26. Liu W, Chen Y, Wang W, Keng P, Finkelstein J, Hu D, Liang L, Guo $M$, Fenton $B$, Okunieff $P$, Ding I: Combination of radiation and celebrex (celecoxib) reduce mammary and lung tumor growth. Am / Clin Oncol 2003, 26:SI 03-109.

27. Newcomb EW, Madonia WJ, Pisharody S, Lang FF, Koslow M, Miller DC: A correlative study of $\mathrm{p} 53$ protein alteration and $\mathrm{p} 53$ gene mutation in glioblastoma multiforme. Brain Pathol 1993, 3:229-235.

28. Norbury C], Zhivotovsky B: DNA damage-induced apoptosis. Oncogene 2004, 23:2797-2808.

29. Zeng $X$, Yan T, Schupp JE, Seo Y, Kinsella TJ: DNA mismatch repair initiates 6-thioguanine-induced autophagy through p53 activation in human tumor cells. Clin Cancer Res 2007, 13:1315-1321.

30. Feng $\mathrm{Z}$, Zhang $\mathrm{H}$, Levine $\mathrm{A}$, J jin $\mathrm{S}$ : The coordinate regulation of the p53 and mTOR pathways in cells. Proc Natl Acad Sci USA 2005, 102:8204-8209.

3I. Klionsky DJ, Emr SD: Autophagy as a regulated pathway of cellular degradation. Science 2000, 290:1717-1721.

32. Crighton D, Wilkinson S, O'Prey J, Syed N, Smith P, Harrison PR Gasco M, Garrone O, Crook T, Ryan KM: DRAM, a p53-induced modulator of autophagy, is critical for apoptosis. Cell 2006, 126: $121-134$.

33. Grosch S, Schilling K, Janssen A, Maier TJ, Niederberger E, Geisslinger $\mathrm{G}$ : Induction of apoptosis by R-flurbiprofen in human colon carcinoma cells: involvement of p53. Biochem Pharmacol 2005 , 69:831-839

34. Ho CC, Yang XW, Lee TL, Liao PH, Yang SH, Tsai CH, Chou MY: Activation of p53 signalling in acetylsalicylic acid-induced apoptosis in OC2 human oral cancer cells. Eur J Clin Invest 2003, 33:875-882

35. Mazzanti R, Platini F, Bottini C, Fantappie O, Solazzo M, Tessitore L: Down-regulation of the HGF/MET autocrine loop induced by celecoxib and mediated by P-gp in MDR-positive human hepatocellular carcinoma cell line. Biochem Pharmacol 2009, 78:2I-32.

36. Pyrko P, Soriano N, Kardosh A, Liu YT, Uddin J, Petasis NA, Hofman FM, Chen CS, Chen TC, Schonthal AH: Downregulation of survivin expression and concomitant induction of apoptosis by celecoxib and its non-cyclooxygenase-2-inhibitory analog, dimethyl-celecoxib (DMC), in tumor cells in vitro and in vivo. Mol Cancer 2006, 5:19.

37. Levine AJ: p53, the cellular gatekeeper for growth and division. Cell 1997, 88:323-331.

38. Komarova EA, Gudkov AV: Suppression of p53: a new approach to overcome side effects of antitumor therapy. Biochemistry (Mosc) 2000, 65:4I-48.

39. McAdam BF, Catella-Lawson F, Mardini IA, Kapoor S, Lawson JA, FitzGerald GA: Systemic biosynthesis of prostacyclin by cyclooxygenase (COX)-2: the human pharmacology of a selective inhibitor of COX-2. Proc Natl Acad Sci USA 1999, 96:272-277.

40. Xu GW, Mymryk JS, Cairncross JG: Pharmaceutical-mediated inactivation of $\mathrm{p} 53$ sensitizes U87MG glioma cells to BCNU and temozolomide. Int J Cancer 2005, I 16:187-192.

4I. Xu GW, Nutt CL, Zlatescu MC, Keeney M, Chin-Yee I, Cairncross JG: Inactivation of p53 sensitizes U87MG glioma cells to I,3bis(2-chloroethyl)-I-nitrosourea. Cancer Res 200I, 61:4155-4I59.

42. el-Deiry WS, Harper JW, O'Connor PM, Velculescu VE, Canman CE, Jackman J, Pietenpol JA, Burrell M, Hill DE, Wang Y, et al.: WAFII CIPI is induced in p53-mediated GI arrest and apoptosis. Cancer Res 1994, 54: I 169-1 174. 
43. Batista LF, Roos WP, Christmann M, Menck CF, Kaina B: Differential sensitivity of malignant glioma cells to methylating and chloroethylating anticancer drugs: p53 determines the switch by regulating xpc, ddb2, and DNA double-strand breaks. Cancer Res 2007, 67:। I886-II895.

44. Yao KC, Komata T, Kondo Y, Kanzawa T, Kondo S, Germano IM: Molecular response of human glioblastoma multiforme cells to ionizing radiation: cell cycle arrest, modulation of the expression of cyclin-dependent kinase inhibitors, and autophagy. J Neurosurg 2003, 98:378-384.

45. Paglin S, Hollister T, Delohery T, Hackett N, McMahill M, Sphicas E, Domingo $D$, Yahalom J: A novel response of cancer cells to radiation involves autophagy and formation of acidic vesicles. Cancer Res 2001, 61:439-444.

46. Levine B, Abrams J: p53: The Janus of autophagy? Nat Cell Biol 2008, 10:637-639.

47. Kabeya Y, Mizushima N, Ueno T, Yamamoto A, Kirisako T, Noda T, Kominami E, Ohsumi Y, Yoshimori T: LC3, a mammalian homologue of yeast Apg8p, is localized in autophagosome membranes after processing. Embo J 2000, 19:5720-5728.

48. Cervi D, Truong AH, Lee JS, Sukhai N, Li YJ, Koki A, Ben-David Y: Phosphorylation status of c-Kit and Epo receptors, and the presence of wild-type p53 confer in vitro resistance of murine erythroleukemic cells to Celecoxib. Oncogene 2004, 23:2305-23i4.

49. Hida $\mathrm{T}$, Yatabe $\mathrm{Y}$, Achiwa $\mathrm{H}$, Muramatsu $\mathrm{H}$, Kozaki K, Nakamura $\mathrm{S}$, Ogawa M, Mitsudomi T, Sugiura T, Takahashi T: Increased expression of cyclooxygenase 2 occurs frequently in human lung cancers, specifically in adenocarcinomas. Cancer Res 1998, 58:376I-3764.

50. Yoshinaka R, Shibata MA, Morimoto J, Tanigawa N, Otsuki Y: COX2 inhibitor celecoxib suppresses tumor growth and lung metastasis of a murine mammary cancer. Anticancer Res 2006, 26:4245-4254

5I. Kang KB, Wang TT, Woon CT, Cheah ES, Moore XL, Zhu C, Wong $M C$ : Enhancement of glioblastoma radioresponse by a selective COX-2 inhibitor celecoxib: inhibition of tumor angiogenesis with extensive tumor necrosis. Int J Radiat Oncol Biol Phys 2007, 67:888-896.

52. Swamy MV, Herzog CR, Rao CV: Inhibition of COX-2 in colon cancer cell lines by celecoxib increases the nuclear localization of active p53. Cancer Res 2003, 63:5239-5242.

53. Hippert MM, O'Toole PS, Thorburn A: Autophagy in cancer: good, bad, or both? Cancer Res 2006, 66:9349-935I.

54. Tessitore L, Bonelli G, Cecchini G, Autelli R, Amenta JS, Baccino FM: Regulation of protein turnover versus growth state. Studies on the mechanism(s) of initiation of acidic vacuolar proteolysis in cells of stationary ascites hepatoma. Biochem J 1988, 25 I:483-490.

55. Ryan EP, Bushnell TP, Friedman AE, Rahman I, Phipps RP: Cyclooxygenase- 2 independent effects of cyclooxygenase- 2 inhibitors on oxidative stress and intracellular glutathione content in normal and malignant human B-cells. Cancer Immunol Immunother 2008, 57:347-358.

56. Seo SK, Lee HC, Woo SH, Jin HO, Yoo DH, Lee SJ, An S, Choe TB, Park MJ, Hong SI, Park IC, Rhee CH: Sulindac-derived reactive oxygen species induce apoptosis of human multiple myeloma cells via p38 mitogen activated protein kinase-induced mitochondrial dysfunction. Apoptosis 2007, 12:195-209.
Publish with Biomed Central and every scientist can read your work free of charge

"BioMed Central will be the most significant development for disseminating the results of biomedical research in our lifetime. "

Sir Paul Nurse, Cancer Research UK

Your research papers will be:

- available free of charge to the entire biomedical community

- peer reviewed and published immediately upon acceptance

- cited in PubMed and archived on PubMed Central

- yours - you keep the copyright

Submit your manuscript here:

http://www.biomedcentral.com/info/publishing_adv.asp
BioMedcentral 